\title{
EFFECT OF THE HEAT TREATMENT OF Hovenia dulcis Thunb. WOOD ON THE PRODUCTION OF EGP PANELS WITH DIFFERENT ADHESIVES
}

\author{
Raquel Marchesan ${ }^{1}$, Edison Toledo Corrêa dos Santos ${ }^{2}$, Rosilani Trianoski ${ }^{3}$, Morgana Cristina França ${ }^{4}$, Pedro \\ Licio Loiola ${ }^{4}$, Antônio José Vinha Zanuncio ${ }^{5}$ \\ ${ }^{1}$ Federal University of Tocantins, Forest Engineering Course, Gurupi, Tocantins, Brazil - raquelmarchesan@uft.edu.br* \\ ${ }^{2}$ Postgraduate Program in Bioenergy (PPGB), UNICENTRO, Guarapuava, Paraná, Brazil - edisontoledo033@gmail.com \\ ${ }^{3}$ Federal University of Paraná, Forest Engineering Department, Curitiba, Paraná, Brasil - rosillani@ gmail.com \\ ${ }^{4}$ Postgraduate Program in Forest Engineering, Department of Forest Engineering, Federal University of Paraná, Curitiba, Paraná, Brazil - \\ morganaa_franca@hotmail.com,pedrlicio@hotmail.com \\ ${ }^{5}$ Federal University of Uberlândia, Forest Engineering Course, Monte Carmelo, Minas Gerais, Brazil - ajvzanuncio@ufu.br \\ Received for publication: 03/03/2019 - Accepted for publication: 21/04/2020
}

\begin{abstract}
Resumo
Efeito da termorretificação da madeira de Hovenia dulcis Thunb. Na produção de painéis egp com diferentes adesivos. O objetivo deste trabalho foi analisar a resistência ao cisalhamento de painéis colados lateralmente (EGP) fabricados a partir da madeira de $H$. dulcis Thunb. modificados termicamente pelo processo VAP HolzSysteme ${ }^{\circledR}$. Primeiramente as amostras de Hovenia dulcis foram termorretificadas pelo processo VAP HolzSysteme ${ }^{\circledR}$, em seguida foram coladas com adesivos Resorcinol-formaldeído (RF), Melamina-uréiaformaldeído (MUF), Emulsão polimérica de isocianato (EPI) e Polivinilacetato (PVAc) e submetidas a prétratamentos para ambiente seco, úmido e externo e sem pré-tratamento para avaliar a resistência ao cisalhamento, $5^{\circ}$ percentil e falha na madeira. Observou-se queda na resistência ao cisalhamento da madeira de H. dulcis termorretificada para todos os adesivos. Todos os adesivos obtiveram resultados superiores ao mínimo exigido pela norma EN13354(2009) para a madeira sem pré-tratamento tanto para a madeira sem termorretificação como para a madeira termorretificada, podendo ser utilizados para fins não estruturais. No entanto, para ambiente externo (três ciclos) somente o adesivo MUF obteve valor que atendesse aos padrões mínimos da norma, desta forma sugere-se para colagem de painel EGP de H. dulcis sem termorretificação e com termorretificação a utilização do adesivo MUF o qual obteve melhor performance oferecendo maior resistência em ambientes secos, úmidos e externos.
\end{abstract}

Palavras-chave: Uva-do-japão. Cisalhamento. VAP HolzSysteme®.

\section{Abstract}

The objective of this work was to analyze the shear strength of edge-glued panels (EGP) made from the $H$. dulcis Thunb. wood thermally modified by the VAP HolzSysteme ${ }^{\circledR}$ process. Initially, the Hovenia dulcis samples were heat-annealed by the VAP HolzSysteme ${ }^{\circledR}$ process, and then bonded with Resorcinolformaldehyde (RF), Melamine-urea-formaldehyde (MUF), Isocyanate Polymer Emulsion (EPI) and Polyvinylacetate (PVAc) and submited to pre-treatments for dry, humid and external environment and without pre-treatment to evaluate the shear strength, 5th percentile and failure in the wood. It was observed a decrease in the shear strength of the thermorrectified H. dulcis wood for all adhesives. All adhesives obtained results superior to the minimum required by the standard EN13354 (2009) for the wood without pre-treatment as for the wood without thermoregulation as well as for the heat treated wood, and may be used for non-structural purposes. However, for the external environment (three cycles) only the MUF adhesive obtained value that meets the minimum standards of the standard, in this way, it is suggested to glue the EGP of $\mathrm{H}$. dulcis without thermortification and with thermorrectification using the MUF adhesive, which has achieved better performance offering greater resistance in dry, wet and external environments.

Keywords: Uva-do-japão. Shearing. VAP HolzSysteme®.

\section{INTRODUCTION}

Heat treatment is a process of modifying wood pieces from the application of heat to high temperatures, which may vary between 180 and $260^{\circ} \mathrm{C}$; below $140^{\circ} \mathrm{C}$, the modifications occurred are irrelevant and, above $260^{\circ}$, the treatment starts to compromise the integrity of the samples (HILL, 2006). According to Cademartori et al. (2012), after $200^{\circ} \mathrm{C}$, changes in physical and mechanical properties become more significant.

The heat treatment processes are those that have evolved the most in commercial terms in recent years. The success is probably due to the low cost of treatment when compared to other modifications that are based on the use of chemical compounds that make the final product more expensive (ESTEVES AND PEREIRA, 2009).

According to Hill (2006), among all the wood modification processes, heat treatment has the most commercially advanced technology, which proposes improvements in dimensional stability by reducing hygroscopicity, improving resistance to biodeterioration and weathering, in addition to changing the color of the

FLORESTA, Curitiba, PR, v. 50, n. 4, p. 1761 - 1769, out/dez 2020.

Marchesan, R. et.al.

ISSN eletrônico 1982-4688 
material. Therefore, the heat treatment is able to improve the qualities of commercial wood, producing alternative products for use and production of materials resistant to external use.

Moura and Brito (2011) added that the heat treatment of wood species of less economic value is an excellent example of adding value. Another process that has been generating higher value-added products is the production of side-glued panels (BELLON et al., 2014).

The side bonding panels are panels produced from a set of wooden battens glued laterally, with or without top bonding by finger-joint splices, and their adhesion is performed with the help of adhesives (TIENNE et al., 2011). Its production allows the use of narrow and short pieces, with small or light defects, residues from sawmills and other forest-based industries, thus increasing the yield through the reuse of a material that was discarded or burned as biomass for energy generation (DANAWADE et al., 2014).

Generally, these two processes are used: heat treatmentand panels glued laterally, in common species in Brazilian reforestations (pinus and eucalyptus). However, to reduce dependencies on pine and eucalyptus wood, the forest-based sector has invested in research in the areas of silviculture and wood technology in search of alternative species of rapid growth for wood production (IWAKIRI et al., 2012). Likewise, Trianoski et al. (2013) highlight the need for studies related to the use of alternative species, in order to increase the diversity and volume of raw material offered to the timber market.

Thus, the species Hovenia dulcis Thunberg (uva-do-japão), emerges as a new species for the timber market. The "uva-do-japão" has been used in silvopastoral, silviagricultural systems and as hedges, and may be destined to the sawmill, with approximately 20 years (CARVALHO, 1994). Selle (2009) suggests H. dulcis as one of the species that presents desirable conditions and characteristics for industrial use, being wood with good characteristics for use in furniture, floors, walls and frames and, in rural areas, in the form of fence posts as well as energy due to its energy potential. However, due to little knowledge of its technological properties, its wood is generally used as firewood in small rural properties (CARPANEZZI, 2010).

In this context, it is necessary to verify the technological behavior of the side glued panels manufactured from $H$. dulcis wood submitted to the heat treatment process, to test its viability regarding the use in high value products (HVP). Therefore, the aim of the present study was to analyze the bonding quality of EGP (Edge-Glued Panel) panels produced with Hovenia dulcis Thunb. wood without heat treatment and thermorectified bonded with four different adhesives.

\section{MATERIAL AND METHODS}

\section{Wood collection and processing}

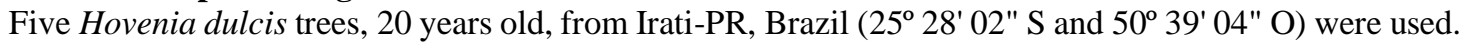
After cutting, the wood was sawn and dried to $12 \%$ moisture. Then, it was sectioned into 20 pieces with dimensions of $25.40 \times 101.00 \times 1000.00 \mathrm{~mm}$ (thickness, width and length), in which 10 pieces were directed to the making of test pieces without heat treatment and 10 pieces for making of thermorectified test pieces.

\section{Wood heat treatment - VH HolzSysteme ${ }^{\circledR}$ hygrothermal process}

Ten pieces with dimensions of $25.40 \times 101.00 \times 1000.00 \mathrm{~mm}$ (thickness, width and length) were subjected to VAP HolzSysteme ${ }^{\circledR}$ heat treatment. This process consists of heating the material to $110^{\circ} \mathrm{C}$ and maintaining the temperature for 25 minutes, then the temperature increases to $155^{\circ} \mathrm{C}$ for 45 minutes and finally it cools down inside the equipment. The heat treatment process followed the company's methodology, represented in Figure 1.

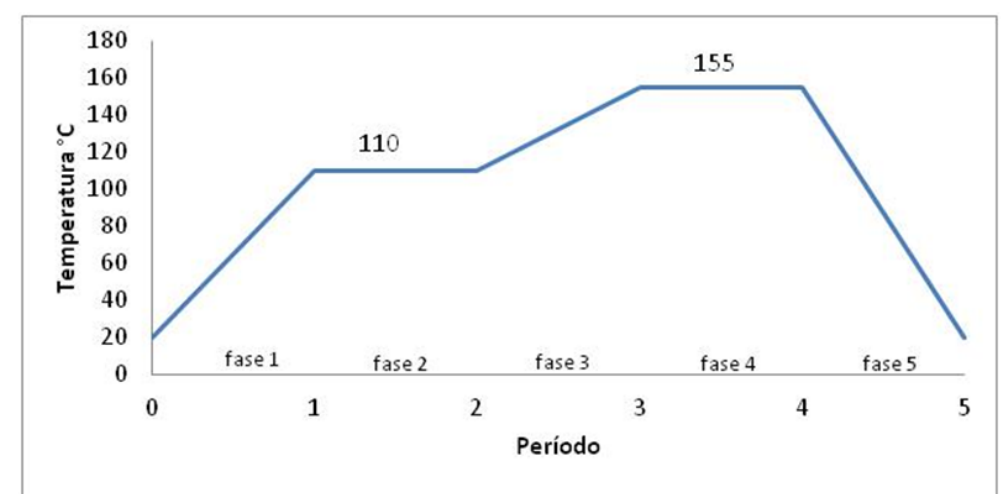

Figure 1. Program of VAP HolzSysteme ${ }^{\circledR}$ heat treatment process.

Figura 1. Programa do processo de termorretificação VAP HolzSysteme ${ }^{\circledR}$.

FLORESTA, Curitiba, PR, v. 50, n. 4, p. 1761 - 1769, out/dez 2020.

Marchesan, R. et.al.

ISSN eletrônico 1982-4688

DOI: $10.5380 /$ rf.v50 i4. 65268 


\section{Wood processing and gluing}

For the preparation of the shear specimens, samples of $25.00 \times 60.00 \times 310.00 \mathrm{~mm}$ (thickness, width and length, respectively) were produced from pieces of $25.40 \times 101.00 \times 1000.00 \mathrm{~mm}$ (thickness, width and length) of treated wood and treatment. Then, the samples were bonded with four adhesives: Polyvinyl Acetate Cross (PVAc), Emulsion Polymer Isocyanate (EPI), Melamine Urea Formaldehyde (MUF) and Resorcinol Formaldehyde (RF), all with weight and homogeneous distribution for the control of variables. The applied weight was $180 \mathrm{~g} / \mathrm{m}^{2}$ and after applying the adhesive, the battens were pressed with a manual press. The pressing time varied between the types of adhesive and followed the instructions of the manufacturer's technical bulletin, two hours for PVAc, one hour for EPI, eight hours for RF and five hours for MUF. After acclimatizing the glued joints, the specimens were made according to standard EN13354 (2009) for each adhesive within each wood treatment and pre-treatment as shown in Table 1.

Table 1. Experimental delimitation.

Tabela 1. Delineamento experimental.

\begin{tabular}{|c|c|c|c|c|}
\hline Treatment & Adhesive & $\begin{array}{l}\text { Pressing time } \\
\text { (hours) }\end{array}$ & Pre-treatment & No. of test pieces \\
\hline \multirow{4}{*}{$\begin{array}{l}\text { Wood without } \\
\text { thermorectification }\end{array}$} & PVAc & 2 & $\begin{array}{c}\text { Dry } \\
\text { Cold water }\end{array}$ & $\begin{array}{l}10 \\
10\end{array}$ \\
\hline & EPI & 1 & $\begin{array}{c}\text { Dry } \\
\text { Cold water }\end{array}$ & $\begin{array}{l}10 \\
10\end{array}$ \\
\hline & $\mathrm{RF}$ & 8 & $\begin{array}{c}\text { Dry } \\
\text { Cold water } \\
\text { Boiling } 6 \mathrm{~h} \\
\text { Three cycles }\end{array}$ & $\begin{array}{l}10 \\
10 \\
10 \\
10\end{array}$ \\
\hline & MUF & 5 & $\begin{array}{c}\text { Dry } \\
\text { Cold water } \\
\text { Boiling 6h } \\
\text { Three cycles }\end{array}$ & $\begin{array}{l}10 \\
10 \\
10 \\
10\end{array}$ \\
\hline \multirow{4}{*}{$\begin{array}{l}\text { Thermorectified } \\
\text { wood }\end{array}$} & PVAc & 2 & $\begin{array}{c}\text { Dry } \\
\text { Cold water }\end{array}$ & $\begin{array}{l}10 \\
10\end{array}$ \\
\hline & EPI & 1 & $\begin{array}{c}\text { Dry } \\
\text { Cold water }\end{array}$ & $\begin{array}{l}10 \\
10\end{array}$ \\
\hline & $\mathrm{RF}$ & 8 & $\begin{array}{c}\text { Dry } \\
\text { Cold water } \\
\text { Boiling 6h } \\
\text { Three cycles }\end{array}$ & $\begin{array}{l}10 \\
10 \\
10 \\
10\end{array}$ \\
\hline & MUF & 5 & $\begin{array}{c}\text { Dry } \\
\text { Cold water } \\
\text { Boiling 6h } \\
\text { Three cycles }\end{array}$ & $\begin{array}{l}10 \\
10 \\
10 \\
10\end{array}$ \\
\hline
\end{tabular}

\section{Shear test pre-treatments}

The samples were tested in simulation tests under extreme conditions, which seek to accelerate the process of deterioration of the adhesive joints (EN13354/2009 Bondin quality - Test method). In this way, the panels were classified based on the conditions of use (dry, humid or outdoor conditions), with pre-treatments determined for each class: without pre-treatment (dry shear), pre-treatment for dry environments (immersion in cold water), humid environments (boiling), external environments (three cycles).

In the condition without pre-treatment, the shear test was performed after the adhesive cured. The test pieces classified in dry environments were pre-treated, which consists of emerging them in water at a temperature of $20^{\circ} \mathrm{C}\left( \pm 3^{\circ} \mathrm{C}\right)$ for 24 hours and immediately after performing tests. The test pieces for humid environments were immersed in water, at boiling temperature for six hours. After this period, they were conditioned in cold water $\left(20^{\circ} \mathrm{C}\right)$ for one hour and soon after the tests were performed.

The test pieces for external use were immersed in water at the boiling temperature for four hours, followed by drying in an oven at $60^{\circ} \mathrm{C}$ for 16 to 20 hours, returning to the boiling water for another four hours; and finally, one hour of cooling in water at $20^{\circ} \mathrm{C}\left( \pm 3^{\circ} \mathrm{C}\right)$ to immediately after performing the shear tests on the glue line. 
The four adhesives (PVAc, EPI, RF and MUF) were used in the test without pre-treatment and in the test with pre-treatment in dry environments. Tests with wet pretreatment and external use were performed only with RF and MUF adhesives. The choice of each adhesive for each type of pre-treatment was based on the condition of use prescribed in the package insert for each adhesive.

\section{Shear strength test on the glue line}

The tests were performed on the test pieces without heat treatment and thermorectified. The test pieces were submitted to the shear test on a universal EMIC testing machine, according to EN 13354 (2009). The results were compared with the minimum requirements established in the standard EN 13353 (2008) in which the glue line failure percentages and the lower 5th percentile were evaluated.

The wood failure was determined with the aid of a transparent checkered film placed over the shear bonded area. The glued area was visually divided into 10 rows x 10 columns, with each grid covering $1 \%$ of its surface during the evaluation. The parts that broke completely in the wood structure and not in the glue line received a maximum percentage of wood failure (100\%).

\section{STATISTICAL ANALYSIS}

The treatments were subjected to a test using a completely randomized design (CRD) with a $2 \times 4$ factorial arrangement scheme, two wood treatments (without thermal treatment and with thermal treatment) and four adhesives (PVAc, EPI, RF and MUF). First, the normality test was performed. Noting the normal data, the homogeneity of variances was tested by the Bartlett test and then applied to ANOVA to verify the existence or not of differences between the factors. If there was a statistical difference between the factors, the Tukey's average comparison test was applied at the $95 \%$ probability level. The programs used for the analyzes were Excel ${ }^{\circledR} 2007$, Statgraphics Centurion XVI.I, and SISVAR 5.6.

\section{RESULTS}

Table 2 contains the average values of maximum stress (MPa), wood failure (\%) and the 5th lower percentile of resistance (MPa) of Hovenia dulcis without heat treatment and thermorectified without pretreatment (dry) with the use of four different adhesives used for bonding the wood.

Table 2. Average results of the shear test on the glue line in the Hovenia dulcis wood performed after dry pretreatment.

Tabela 2. Resultados médios do ensaio de cisalhamento na linha de cola na madeira Hovenia dulcis realizado após o pré-tratamento a seco.

\begin{tabular}{|c|c|c|c|c|c|c|c|}
\hline \multirow[b]{2}{*}{$\begin{array}{c}\text { Pre- } \\
\text { treatment }\end{array}$} & \multirow[b]{2}{*}{ Adhesive } & \multicolumn{3}{|c|}{ Wood without thermorectification } & \multicolumn{3}{|c|}{ Thermorectified Wood } \\
\hline & & Shear (MPa) & $\begin{array}{c}\text { Wood } \\
\text { failure } \\
(\%)\end{array}$ & $\begin{array}{c}\text { 5th low. } \\
\text { perc. } \\
\text { (MPa) }\end{array}$ & Shear (MPa) & $\begin{array}{c}\text { Wood } \\
\text { failure } \\
(\%)\end{array}$ & $\begin{array}{c}\text { 5th low. perc. } \\
\text { (MPa) }\end{array}$ \\
\hline \multirow{5}{*}{ Dry } & PVAc & $\begin{array}{c}15.80 \mathrm{aA} \\
(0.69 ; 4.34)\end{array}$ & 40 & 15.07 & $\begin{array}{c}8.65 \mathrm{bB} \\
(0.70 ; 8.10)\end{array}$ & 77 & 7.94 \\
\hline & EPI & $\begin{array}{c}12.96 \mathrm{bA} \\
(0.89 ; 6.88)\end{array}$ & 33 & 12.23 & $\begin{array}{c}11.31 \mathrm{aB} \\
(1.05 ; 9.30)\end{array}$ & 90 & 10.14 \\
\hline & $\mathrm{RF}$ & $\begin{array}{c}10.55 \mathrm{cA} \\
(0.52 ; 4.93)\end{array}$ & 0 & 10.06 & $\begin{array}{c}3.82 \mathrm{cB} \\
(0.43 ; 11.14)\end{array}$ & 25 & 3.40 \\
\hline & MUF & $\begin{array}{c}15.46 \mathrm{aA} \\
(0.89 ; 5.79) \\
\end{array}$ & 49 & 14.58 & $\begin{array}{c}11.31 \mathrm{aB} \\
(0.36 ; 3.19)\end{array}$ & 100 & 10.84 \\
\hline & $\mathrm{F}$ & & & & $0,33 *$ & & \\
\hline
\end{tabular}

The averages followed by the same lowercase letter in the column and uppercase in the row do not differ statistically from each other by the Tukey test $(5 \%)$. * significant at the $5 \%$ probability level $(01=<\mathrm{p}<0.05)$. The values in parentheses correspond to the standard deviation and coefficient of variation $(\%)$, respectively.

According to Table 2, considering the specimens that did not receive heat treatment, without pretreatment, it is observed that those made with the MUF and PVAc adhesive were statistically superior to the others, however for those that were heat-treated, MUF and EPI were superior. It may be noted that for both treatments the EGPs bonded with RF were statistically inferior to the others.

FLORESTA, Curitiba, PR, v. 50, n. 4, p. 1761 - 1769, out/dez 2020

Marchesan, R. et.al.

ISSN eletrônico 1982-4688

DOI: $10.5380 /$ rf.v50 i4. 65268 
Table 3 shows the average values of maximum stress (MPa), wood failure (\%) and the lower fifth percentile of resistance $(\mathrm{MPa})$ of Hovenia dulcis without thermal treatment and with thermal treatment, for the pre-treatment with immersion in cold water (dry environments) with the use of four different adhesives used for bonding the wood.

Table 3. Average results of the shear test on the glue line in the Hovenia dulcis wood performed after immersion in cold water.

Tabela 3. Resultados médios do ensaio de cisalhamento na linha de cola na madeira Hovenia dulcis realizado após imersão em água fria.

\begin{tabular}{|c|c|c|c|c|c|c|c|}
\hline \multirow[b]{2}{*}{$\begin{array}{c}\text { Pre- } \\
\text { treatment }\end{array}$} & \multirow[b]{2}{*}{ Adhesive } & \multicolumn{3}{|c|}{ Wood without thermorectification } & \multicolumn{3}{|c|}{ Thermorectified Wood } \\
\hline & & Shear (MPa) & $\begin{array}{c}\text { Wood } \\
\text { failure } \\
(\%)\end{array}$ & $\begin{array}{c}\text { 5th low. } \\
\text { perc. } \\
\text { (MPa) }\end{array}$ & Shear (MPa) & $\begin{array}{c}\text { Wood } \\
\text { failure } \\
(\%)\end{array}$ & $\begin{array}{c}\text { 5th low. perc. } \\
\text { (MPa) }\end{array}$ \\
\hline \multirow{5}{*}{$\begin{array}{l}\text { Immersion } \\
\text { in cold } \\
\text { water }\end{array}$} & PVAc & $\begin{array}{c}4.91 \mathrm{bA} \\
(0.46 ; 9.32)\end{array}$ & 0 & 4.37 & $\begin{array}{c}3.01 \mathrm{bcB} \\
(0.23 ; 7.49)\end{array}$ & 1 & 2.79 \\
\hline & EPI & $\begin{array}{c}9.74 \mathrm{aA} \\
(0.57 ; 5.83)\end{array}$ & 0 & 9.24 & $\begin{array}{c}2.48 \mathrm{cB} \\
(0.10 ; 4.23)\end{array}$ & 3 & 2.35 \\
\hline & $\mathrm{RF}$ & $\begin{array}{c}10.52 \mathrm{aA} \\
(1.29 ; 12.26)\end{array}$ & 10 & 9.25 & $\begin{array}{c}3.78 \mathrm{bB} \\
(0.46 ; 12.22)\end{array}$ & 14 & 3.19 \\
\hline & MUF & $\begin{array}{c}10.06 \mathrm{aA} \\
(0.28 ; 2.82)\end{array}$ & 20 & 9.71 & $\begin{array}{c}7.89 \mathrm{aB} \\
(0.53 ; 6.67)\end{array}$ & 59 & 7.40 \\
\hline & $\mathrm{F}$ & \multicolumn{6}{|c|}{$58.45^{*}$} \\
\hline
\end{tabular}

The averages followed by the same lowercase letter in the column and uppercase in the row do not differ statistically from each other by the Tukey test $(5 \%)$. * significant at the $5 \%$ probability level $(01=<\mathrm{p}<0.05)$. The values in parentheses correspond to the standard deviation and coefficient of variation $(\%)$, respectively.

It is observed in Table 3, for the pretreatment in cold water for wood without thermal treatment, that the specimens made with the EPI, RF and MUF adhesives were statistically superior when compared to the PVAc adhesive; however, for heat-treated wood there was a significant difference between all adhesives, with MUF being the most resistant in the glue line (7.89 MPa) and EPI being the least resistant $(2.48 \mathrm{MPa})$.

Table 4 shows the average values of maximum stress (MPa), wood failure (\%) and the lower fifth percentile of resistance (MPa) of Hovenia dulcis without thermal treatment and with thermal treatment, for pretreatment with boiling (humid environments) with the use of two different adhesives used for bonding the wood.

Table 4. Average results of the shear test on the glue line in Hovenia dulcis wood performed after boiling pretreatment for RF and MUF adhesives.

Tabela 4. Resultados médios do ensaio de cisalhamento na linha de cola na madeira Hovenia dulcis realizado após o pré-tratamento em fervura para os adesivos RF e MUF.

\begin{tabular}{|c|c|c|c|c|c|c|c|}
\hline \multirow[b]{2}{*}{$\begin{array}{c}\text { Pre- } \\
\text { treatment }\end{array}$} & \multirow[b]{2}{*}{ Adhesive } & \multicolumn{3}{|c|}{ Wood without thermorectification } & \multicolumn{3}{|c|}{ Thermorectified Wood } \\
\hline & & Shear (MPa) & $\begin{array}{c}\text { Wood } \\
\text { failure } \\
(\%)\end{array}$ & $\begin{array}{c}\text { 5th low. } \\
\text { perc. (MPa) }\end{array}$ & Shear (MPa) & $\begin{array}{c}\text { Wood } \\
\text { failure } \\
(\%)\end{array}$ & $\begin{array}{c}\text { 5th low. perc. } \\
\text { (MPa) }\end{array}$ \\
\hline \multirow{3}{*}{ Boiling } & $\mathrm{RF}$ & $\begin{array}{c}8.31 \mathrm{aA} \\
(1.02 ; 12.27)\end{array}$ & 7 & 7.07 & $\begin{array}{c}3.43 \mathrm{aB} \\
(0.41 ; 12.02)\end{array}$ & 47 & 3.03 \\
\hline & MUF & $\begin{array}{c}8.38 \mathrm{aA} \\
(0.84 ; 9.98)\end{array}$ & 22 & 7.55 & $\begin{array}{c}4.3 \mathrm{aB} \\
(0.56 ; 13.05)\end{array}$ & 60 & 3.78 \\
\hline & $\mathrm{F}$ & \multicolumn{6}{|c|}{$0.241^{\mathrm{ns}}$} \\
\hline
\end{tabular}

The averages followed by the same lowercase letter in the column and uppercase in the row do not differ statistically from each other by the Tukey test $(5 \%)$. ${ }^{\text {ns }}$ Not significant at the $5 \%$ probability level $(01=<p<0.05)$. The values in parentheses correspond to the standard deviation and coefficient of variation $(\%)$, respectively.

It may be seen in Table 4, in the pre-treatment with boiling (humid environments), that between the RF and MUF adhesives there was statistical equality both for wood without heat treatment and for thermorrectified; however, within the same adhesive, between the treatments of wood without heat treatment and thermorrectified

FLORESTA, Curitiba, PR, v. 50, n. 4, p. 1761 - 1769, out/dez 2020.

Marchesan, R. et.al.

ISSN eletrônico 1982-4688

DOI: $10.5380 /$ rf.v50 i4. 65268 
there was a significant difference, in which wood without Heat treatmentwas again more resistant to shear in the glue line.

Table 5 shows the average values of maximum stress (MPa), wood failure (\%) and the 5 th lower percentile of resistance $(\mathrm{MPa})$ of Hovenia dulcis without heat treatment and thermorectified, for the pretreatment of three cycles (external environment) using two different adhesives used for bonding the wood.

Table 5. Average results of the shear test on the glue line in the Hovenia dulcis wood performed after the pretreatment in three cycles for RF and MUF adhesives.

Tabela 5. Resultados médios do ensaio de cisalhamento na linha de cola na madeira Hovenia dulcis realizado após o pré-tratamento em três ciclos para os adesivos RF e MUF.

\begin{tabular}{|c|c|c|c|c|c|c|c|}
\hline \multirow[b]{2}{*}{$\begin{array}{c}\text { Pre- } \\
\text { treatment }\end{array}$} & \multirow[b]{2}{*}{ Adhesive } & \multicolumn{3}{|c|}{ Wood without thermorectification } & \multicolumn{3}{|c|}{ Thermorectified Wood } \\
\hline & & Shear (MPa) & $\begin{array}{c}\text { Wood } \\
\text { failure } \\
(\%)\end{array}$ & $\begin{array}{l}\text { 5th low. } \\
\text { perc. } \\
\text { (MPa) }\end{array}$ & Shear (MPa) & $\begin{array}{c}\text { Wood } \\
\text { failure }(\%)\end{array}$ & $\begin{array}{c}\text { 5th low. } \\
\text { perc. } \\
\text { (MPa) }\end{array}$ \\
\hline \multirow[b]{2}{*}{$\begin{array}{l}\text { Three } \\
\text { cycles }\end{array}$} & $\mathrm{RF}$ & $\begin{array}{c}3.69 \mathrm{bA} \\
(1.20 ; 32.41)\end{array}$ & 2 & 2.29 & $\begin{array}{c}2.03 \mathrm{bB} \\
(0.43 ; 21.01)\end{array}$ & 23 & 1.50 \\
\hline & MUF & $\begin{array}{c}7.10 \mathrm{aA} \\
(0.89 ; 12.60)\end{array}$ & 10 & 6.21 & $\begin{array}{c}3.31 \mathrm{aB} \\
(0.19 ; 5.82)\end{array}$ & 53 & 3.10 \\
\hline
\end{tabular}

The averages followed by the same lowercase letter in the column and uppercase in the row do not differ statistically from each other by the Tukey test $(5 \%)$. * significant at the $5 \%$ probability level $(01=<\mathrm{p}<0.05)$. The values in parentheses correspond to the standard deviation and coefficient of variation $(\%)$, respectively.

It may be seen in Table 5, in the pre-treatment three cycles for external environments that there was a statistically significant difference between the RF and MUF adhesives both for wood without heat treatment nd for thermorectified wood and also within the same adhesive, between treatments of wood without Heat treatmentand thermorectified, with the MUF adhesive on wood without Heat treatmentwith an average shear of 7.01 MPa.

\section{DISCUSSION}

When analyzing each adhesive in the dry pretreatment in Table 2, it may be seen that, for all specimens tested without thermal treatment, they presented higher shear averages than the thermorectified ones. This fact probably happened due to the heat treatment exuding extracts for the wood surface, impairing the gluing efficiency and consequently the resistance to the shear test. Esteves and Pereira (2009) corroborate that the hygroscopic sites that absorb the humidity of the environment and increase the equilibrium humidity of the wood are also responsible for the chemical bond with the adhesive and, according to Carvalho et al. (2015), the decomposition of these sites hinders the mechanical bonding of the adhesive with the wood, reducing the shear strength after heat treatments with higher temperatures.

Iwakiri et al. (2013), in a study using Eucalyptus benthamii and PVAc adhesive, obtained values of 9.04 MPa for the shear strength, being lower than the present study in comparison with wood without thermal treatment and superior when compared with thermorectified wood. Plaster et al. (2012), using Eucalyptus urograndis wood and the PVAc and RF adhesives, found a lower performance for the shear strength in the glue line (11.33 MPa) with the use of PVAc when compared with $H$. dulcis wood without thermal treatment and higher when compared with the thermorectified $H$. dulcis wood.

Marchesan et al. (2018) in a study on the production of EGP with the H. dulcis wood, found shear values in the dry pretreatment for the PVAc and EPI adhesives of 6.33 and $12.60 \mathrm{MPa}$, respectively. It is noted that the PVAc adhesive showed a lower value than that found in the present study, while the EPI showed a similar value. The difference in the resistance values obtained for the same species and the same adhesive, may be related to the wood moisture, adhesive viscosity, glue line failure, among other factors.

Still with regard to dry pretreatment (Table 2), studies were found that showed similar results to those found in this research. Vital et al. (2006) found, for E. saligna and E. grandis wood glued with PVAc, shear strength values of 10.24 and $9.12 \mathrm{MPa}$, respectively. Iwakiri et al. (2013) found for Eucaplyptus benthamii wood glued with PVAc, average shear value of $9.04 \mathrm{MPa}$.

Regarding wood failure, the standard EN 13353 (2003) establishes a minimum percentage of 40\%. Thus, it may be seen in Table 2 that the wood without thermal treatment in the dry pre-treatment showed values according

FLORESTA, Curitiba, PR, v. 50, n. 4, p. 1761 - 1769, out/dez 2020.

Marchesan, R. et.al.

ISSN eletrônico 1982-4688

DOI: $10.5380 /$ rf.v50 i4. 65268 
to the standard for PVAc and MUF adhesives of $40 \%$ and $49 \%$ respectively, while for the EPI and RF adhesives, the wood failure values were lower than the stipulated by the standard ( 33 and $0 \%$ respectively).

For heat-treated wood in the dry pre-treatment, PVAc, EPI and MUF adhesives were in accordance with the standard (77, 90 and 100\% respectively). The RF adhesive was found to be below the stipulated value of $40 \%$ of wood failure (25\%). The MUF adhesive was the most efficient in relation to the strength of the glue line, both in untreated H. dulcis wood (49\% wood failure) and in heat treated wood (100\% wood failure).

Iwakiri (2016) also obtained better values for the MUF adhesive. However, it is clear that there is a wide range of variation in the results obtained for the wood failure in the present study, a fact that corroborates with studies performed by other authors such as Plaster et al. (2008) and Bila et al. (2016).

According to Bila et al. (2016), generally when the percentage of wood failure varies between $0-25 \%$ the result suggests low adhesive resistance and/or deficiency in the bonding process such as smooth surface, low applied weight, high surface humidity, among others; between 50-70\% suggests a more adequate situation of the gluing process and properties of the adhesive and between $75 \%$ and $100 \%$, stronger adhesion properties are found.

The conditions without thermal treatment, in the dry pre-treatment showed a higher maximum stress and less failure in the wood compared to the thermorectified wood. According to Esteves; Pereira (2009) and Kacikova et al. (2013) the heat treatment reduces the resistance of the wood due to the degradation of carbohydrates, however, the resistance of the adhesive remains the same, that is, it may increase or maintain the percentage of wood failure in conditions with heat treatment, a fact that was proven in the present work.

For the 5th lower percentile in which the standard EN 13353 (2003) establishes a minimum value of 2.5 $\mathrm{MPa}$, Table 2 also shows that all adhesives in the dry pre-test for non-heat treated and thermorectified wood were within the value stipulated by the standard. In addition, it may be highlighted that the treatments without heat treatment showed higher values than those certified, when analyzing the same adhesive in the dry pre-treatment.

When comparing the two treatments (without heat treatment and with thermorectification) presented in Table 3 for pre-treatment in a dry environment, it is observed that again all adhesives applied to the wood without treatment were statistically superior to the wood with thermorectification.

Iwakiri et al. (2015) in a study on the resistance evaluation of joints bonded from the Cryptomeria japonica and Sequoia sempervirens woods with PVA and EPI adhesives in the pre-treatment in cold water immersion, obtained higher shear values than those of $\mathrm{H}$. dulcis wood without heat treatment for the PVAc adhesive of 8.32 MPa for $C$. japonica and $9.35 \mathrm{MPa}$ for $S$. sempervirens. For the EPI adhesive, the values may be considered close, 9.63 MPa for $C$. japonica and $10.39 \mathrm{MPa}$ for $S$. sempervirens. In the case of thermorectified $H$. dulcis wood, both adhesives showed lower shear values than those presented by the authors.

For the result of wood failure, it is also observed in Table 3 that only the MUF adhesive used in the thermorectified wood was within the stipulated by the standard EN 13353 (2003) with an average of 59\%. The others presented values well below the norm indicating that there were failures in the glue line, suggesting that the pre-treatment in cold water contributed to the degradation of the adhesives. Iwakiri et al. (2015) observed that the adhesive obtained better results from wood failures, a fact that did not occur in the present study. Iwakiri et al. (2016) and Bila (2016) also obtained values below $40 \%$ for the pretreatment in cold water immersion, confirming the results of the present study.

In relation to the lower 5 th percentile (minimum value of $2.5 \mathrm{MPa}$ ), it is noted in Table 3 that only the EPI adhesive on the heat-treated wood was below that required by the standard EN 13353 (2003), the others were found above $2.5 \mathrm{MPa}$ in the two treatments of the $H$. dulcis.

Ivakiri et al. (2015) found higher values of the 5th percentile for both species (Cryptomeria japonica and Sequoia sempervirens) and for the two adhesives studied (PVAc and EPI).

Following the parameter of side bonding quality, it may be said that in general the H. dulcis Thunb. wood, without heat treatment or thermorectified, presented satisfactory results with the tested adhesives, both without pre-treatment and in a dry environment (immersion in cold water). However, the EPI adhesive obtained a 5th percentile below the value determined by the standard for thermorectified wood.

According to Iwakiri et al. (2016) the shear tests of glued joints after wet pre-treatment (TABLE 4) are little performed as standard procedures for assessing the quality of glue. In a study performed with the species Dinizia excelsa Ducke and Protium puncticulatum J. F. Macbr using the PVAc, EPI and MUF adhesives, obtained lower average shear values than those found in this study in the wet pre-treatment for $\mathrm{H}$. Dulcis wood without thermorectification, being 5.04 MPa for PVAc D3 adhesive, 3.18 MPa for PVAc D4, 3.62 MPa for EPI adhesive and 2.08 MPa for MUF adhesive. However, when compared to the values found for the H. dulcis thermorectified wood, the PVAc and EPI adhesives are close and the MUF is lower than the present study.

It is also noted in Table 4 that only the thermorectified wood was within the required by the standard for the wood failure value (40\%) for the two adhesives. The wood without heat treatment had a wood failure of less than $40 \%$, indicating that there were failures in the glue line, also suggesting that the boiling pretreatment for humid environments contributed to the degradation of the RF and MUF adhesives. Regarding the lower 5th

FLORESTA, Curitiba, PR, v. 50, n. 4, p. 1761 - 1769, out/dez 2020

Marchesan, R. et.al.

ISSN eletrônico 1982-4688

DOI: $10.5380 /$ rf.v50 i4. 65268 
percentile, both the RF adhesive and the MUF in the two treatments of $H$. dulcis wood were approved with values above 2.5 MPa. The wood without heat treatment is highlighted with the MUF adhesive with 7.55 MPa.

Iwakiri et al. (2016) found in a study with Dinizia excelsa Ducke and Protium puncticulatum J. F. Macbr average values for the MUF of $1.24 \mathrm{MPa}$ of $5^{\circ}$ and $0 \%$ of wood failure, lower than those found in this study for the same adhesive in the wet pre-treatment.

Lima et al. (2008), using the RF adhesive, found a percentage of wood failure percentage of $61.23 \%$ in the wood of eucalyptus clones, higher than the average found for the same adhesive in the two wood treatments of H. dulcis (7 and $47 \%$, respectively).

Table 5 shows that only thethermorectified wood glued with the MUF adhesive was within the standard required for the wood failure value $(40 \%)$ with $53 \%$, showing that there were flaws in the glue line and that the boiling pretreatment for outdoor environments contributed to the degradation of RF and MUF adhesives.

Regarding the lower 5th percentile, only the MUF adhesive in the two treatments of $\mathrm{H}$. dulcis wood was approved with values above $2.5 \mathrm{MPa}$. Once again, the wood without heat treatment stood out with an average of 6.61 MPa.

\section{CONCLUSION}

- The use of H. dulcis wood in the production of EGP panels is feasible, as it obtained results of resistance and failure in the wood accepted by the standard EN13354 (2009).

- It was possible to observe a decrease in the mechanical resistance of the wood to shear in the glue line with the use of thermally modified $H$. dulcis wood, also presenting a higher percentage of wood failure when compared to wood without thermal treatment.

- $\quad$ PVAc, EPI, RF and MUF adhesives obtained results higher than the minimum required by the standard EN13354 (2009) on wood without heat treatment and thermorectified, both without pre-treatment, and may be used for non-structural purposes.

- For dry environments (pre-treatment in immersion in cold water) only the EPI adhesive was below the standard EN13354 (2009) for H. dulcis thermorectified wood.

- For the pre-treatment of humid environments (boiling), both the RF and the MUF adhesive, in both treatments of $H$. dulcis wood, obtained values above the stipulated by the norm for the 5 th percentile.

- In external conditions, only the MUF adhesive showed an adequate value for the standard for the 5th percentile in the two treatments of $H$. dulcis wood.

- $\quad$ It is suggested to glue the H. dulcis EGP panel, both without heat treatment and thermorectified, the use of MUF adhesive which obtained better performance offering greater resistance in dry, humid and external environments.

\section{REFERENCES}

BELLON, K. R. R.; LOIOLA, P. L.; JUIZO, C. G. F.; MARCHESAN, R.; SAKOWICZ, E.; KLITZKE, R. J.; ROCHA, M. P. The effect of the thermal modification temperature in the resistance to the parallel compression of fiber for Eucalyptus grandis, Pinus taeda and Tectona grandis wood. Australian Journal of Basic and Applied Sciences, v. 8, p. 512-520, 2014.

BILA, N. F; IWAKIRI, S.; TRIANOSKI, R.; PRATA, J. G. Avaliação da qualidade de juntas coladas de seis espécies de madeiras tropicais da Amazônia. Floresta, Curitiba, v. 46, n. 4, p. 455 - 464, 2016.

CADEMARTORI, P. H. G; SCHNEID, E.; GATTO, D. A.; BELTRAME, R.; STANGERLIN, D. M. Modification of Static Bending Strength Properties of Eucalyptus grandis Heat-Treated Wood. Materials Reasearch, v. 15, n. 2, p. 922-927, 2012

CARPANEZZI, A. A.; NEVES, E. J. M.; AGUIAR, A. V. de; SOUSA, V. A. de. Espécies lenhosas alternativas para fins econômicos no Paraná. In: II Seminário de Atualização Florestal e XI Semana de Estudos Florestais, Embrapa Florestas. Anais...Colombo-PR, 2010.

CARVALHO, P. E. R. Ecologia, silvicultura e usos da uva-do-japão (Hovenia dulcis Thunberg). Colombo: EMBRAPA-CNPF, 1994. 24p. (EMBRAPA-CNPF. Circular técnica, 23).

CARVAlHO, A. G.; DONATO, D. B.; ZANUNCIO, A. J. V.; CARNEIRO, A. C. O.; VITAL, B. R.; FREITAS, F. P. Colagem da madeira de pinus termorretificada. Ciência da Madeira, v. 6, n. 3, p. 217-222, 2015.

CEN - EUROPEAN COMMITTEE FOR STANDARDIZATION. EN 13354: Solid Wood panels (SWP) bonding quality. Bruxelas, 2008. $10 \mathrm{p}$.

FLORESTA, Curitiba, PR, v. 50, n. 4, p. 1761 - 1769, out/dez 2020.

Marchesan, R. et.al. 
CEN - EUROPEAN COMMITTEE FOR STANDARDIZATION. EN 13353: Solid wood panels (SWP) Requirements. Bruxelas, 2008. 13 p.

DANAWADE, B. A.; MALAGI, R. R.; PATIL, B. S.; HANAMAPURE R. S. Effect of finger joint on flexural strength of teak wood. International Journal of Engineering and Technology, v. 5, n. 6, p. 4929-4937, 2014.

ESTEVES, B. M.; PEREIRA, H. M. Wood modification by heat treatment: A Review. BioResources, v. 4, n. 1, p. 370-404, 2009.

HILL, C., Wood Modification - Chemical, Thermal and Other Processes. Wiley Series in Renewable Resources, John Wiley \& Sons, Ldt. 2006.

IWAKIRI, S.; MATOS, J. L. M. de; TRIANOSKI, R.; PRATA, J. G.; Produção de painéis aglomerados homogêneos e multicamadas de Melia azedarach (Cinamomo) e Pinus taeda com diferentes teores de resina. Cerne, Lavras, v. 18, n. 3, p. 465-470, 2012.

IWAKIRI, S.; TRIANOSKI, R.; CUNHA, A.B.; PRATA, J.G.; HARA, M.; BILA, N.F.; LUIS, R.C.G.; ARAUJO, R.D.; BOAS, B.T.V.; - Avaliação da resistência de juntas coladas da madeira de Eucalyptus benthamii com diferentes adesivos e faces de colagem. Scientia forestalis, v. 41, n.99, 2013.

IWAKIRI, S.; TRIANOSKI, R.; FRANÇA, R. F.; GONÇALVES, T. A. P.; LOIOLA, P. L.; CAMPELO, S. R.; FARIAS, S. M. A. P. Avaliação da resistência de juntas coladas da madeira de Cryptomeria japonica e Sequoia sempervirens com diferentes adesivos. Scientia Forestalis, Piracicaba, v. 43, n. 105, p. 19-26, 2015.

IWAKIRI, S.; TRIANOSKI, R.; FONTE, A. P. N.; FRANÇA, M. C.; LAU, P. C.; MOLLEKEN, R. Potencial de uso de madeiras de Dinizia excelsa Ducke e Protium puncticulatum J.F.Macbr para produção de painéis EGP. Scientia Forestalis, Piracicaba, v.44, n. 11, p. 709-717, 2016.

KACIKOVÁ, D., KACIK, F.; CABALOVÁ, I.; DURKOVIC, J. Effects of thermal treatment on chemical, mechanical and colour traits in Norway spruce wood. Bioresource Technology, Mohali, v. 144, p. 669-674, 2013.

LIMA, C. K. P.; MORI, F. A.; MENDES, L. M.; TRUGILHO, P. F.; MORI, C. L. S. O. Colagem da madeira de clones de Eucalyptus com três adesivos comerciais. Scientia Forestalis, Piracicaba, v. 36, n. 77, p. 73-77, 2008.

MARCHESAN, R.; LOIOLA, P. L.; MELLO, T. V.; ROCHA, M. P.; SILVA, J. R. M. Technological feasibility of Hovenia dulcis thunb. species for the production of edge glued panels. Floresta e Ambiente, Seropédica, v. 25, n. 2, p. $1-7,2018$.

MOURA, L. F.; BRITO, J. O. Efeito da termorretificação sobre as propriedades colorimétricas das madeiras de Eucalyptus grandis e Pinus caribaea var. hondurensis. Scientia Forestalis, Piracicaba, v. 39, n. 89, p. 69-76, 2011.

PLASTER, O. B.; OLIVEIRA, J. T. S.; ABRAHÃO, C. P.; BRAZ R. L. Comportamento de juntas coladas da madeira serrada de Eucalyptus sp. Cerne, Lavras, v. 14, n. 3, p. 251-258, 2008.

SELlE, G. L.; FLEIG, F. D.; VUADEN, E.; ALBERNARD, L. A. J.; BRAZ, E. M. Índices de sítios para Hovenia dulcis Thunberg na região central do estado do Rio Grande do Sul, Brasil. Ciência Florestal, Santa Maria, v. 19, n. 4, p. 407-423, 2009.

TIENNE, D. L. D. C.; NASCIMENTO, A. M.; GARCIA, R. A.; SILVA, D. B. Qualidade de adesão de juntas de madeira de pinus coladas em condições simuladas de serviço interna e externa. Floresta e Ambiente, Seropédica, v. 18, n. 1, p. 16-29, 2011.

TRIANOSKI, R.; IWAKIRI, S.; MATOS, J. L. M. de; CHIES, D.; Utilização da madeira de Cryptomeria japonica para produção de painéis aglomerados. Scientia Forestalis, Piracicaba, v. 41, n. 97, p. 57 - 64, 2013.

VITAL, B. R.; MACIEL, A. S.; DELLA LUCIA, R. M. Qualidade de juntas coladas com lâminas de madeiras de três regiões do tronco de Eucalyptus grandis, Eucalyptus salignae Pinus elliottii. Árvore, Viçosa, v. 30, n. 4, p. 637-644, 2006. 